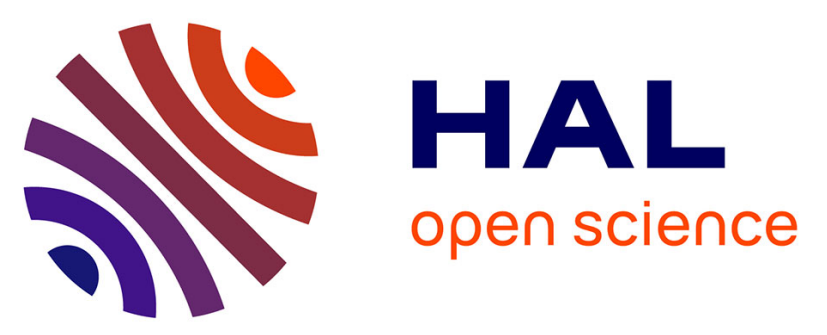

\title{
PREDICTION OF ADHERENCE TO ANTIRETROVIRAL THERAPY: CAN PATIENTS' GENDER PLAY SOME ROLE? AN ITALIAN PILOT STUDY (AIDSIMPACT SPECIAL ISSUE)
}

Alessandro Ubbiali, Deborah Donati, Carlo Chiorri, Valentina Bregani, Elisabetta Cattaneo, Cesare Maffei, Raffaele Visintini

\section{To cite this version:}

Alessandro Ubbiali, Deborah Donati, Carlo Chiorri, Valentina Bregani, Elisabetta Cattaneo, et al.. PREDICTION OF ADHERENCE TO ANTIRETROVIRAL THERAPY: CAN PATIENTS' GENDER PLAY SOME ROLE? AN ITALIAN PILOT STUDY (AIDSIMPACT SPECIAL ISSUE). AIDS Care, 2008, 20 (05), pp.571-575. 10.1080/09540120701867172 . hal-00513455

\author{
HAL Id: hal-00513455 \\ https://hal.science/hal-00513455
}

Submitted on 1 Sep 2010

HAL is a multi-disciplinary open access archive for the deposit and dissemination of scientific research documents, whether they are published or not. The documents may come from teaching and research institutions in France or abroad, or from public or private research centers.
L'archive ouverte pluridisciplinaire HAL, est destinée au dépôt et à la diffusion de documents scientifiques de niveau recherche, publiés ou non, émanant des établissements d'enseignement et de recherche français ou étrangers, des laboratoires publics ou privés. 

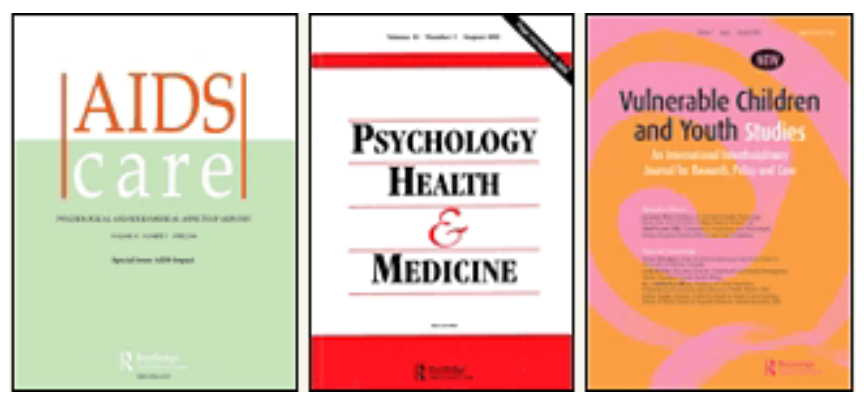

PREDICTION OF ADHERENCE TO ANTIRETROVIRAL THERAPY: CAN PATIENTS' GENDER PLAY SOME ROLE? AN ITALIAN PILOT STUDY (AIDSIMPACT SPECIAL ISSUE)

\begin{tabular}{|r|l|}
\hline Journal: & $\begin{array}{l}\text { AIDS Care - Psychology, Health \& Medicine - Vulnerable Children } \\
\text { and Youth Studies }\end{array}$ \\
\hline Manuscript ID: & AC-2007-08-0448.R1 \\
\hline Journal Selection: & AIDS Care \\
\hline Keywords: & $\begin{array}{l}\text { Adherence, Gender Differences, Adult Attachment Style, Locus of } \\
\text { Control }\end{array}$ \\
\hline \multicolumn{2}{|l}{} \\
\hline
\end{tabular}

\section{ScholarONE" \\ Manuscript Central}




\begin{abstract}
Recent literature has shown that adherence to HAART is a multi-faceted phenomenon, which involves both behavioural and psychological features. Therefore, the results obtained so far, though promising, have not yet unambiguously identified the factors that could predict non-adherence. Since any support for strengthening the adherence should take into account the HIV + patients' perception of both their state of health and their relational style, this study tried to identify some psychological characteristics involved in the adherence phenomenon. A self-administered battery of tests including the Attachment Style Questionnaire and the Multidimensional Health Locus of Control Form-C, was administered to an Italian sample. Results showed significant gender differences between non-adherent vs. adherent subjects. Specifically, the psychological profile of non-adherent males seemed focus less on relational aspects and perceived relevance of physicians and of 'significant other people', whilst that of non-adherent females seemed more 'relationship-oriented'. This study means to encourage clinicians to plan specific, gender- focused support for enhancing adherence.
\end{abstract}




\section{Introduction}

There have been many studies on HIV+ subjects aiming to investigate factors that are helpful for predicting adherence to highly active antiretroviral therapy (HAART) (e.g., Barclay, Hinkin, Castellon et al., 2007; Conway, 2007; Fogarty, Roter, Larson, et al., 2002; Miller \& Hays, 2000; Reynolds, 2004).

As demonstrated in previous reviews on the adherence phenomenon (Osterberg \& Blaschke, 2005), it seems there are no theories of adherence per $s e$, but many models or theories used in practice to predict variables in behavioural adherence.

The majority of the research literature on adherence, has focused on manifest behaviour and therefore assessed the association between 'evident' subject variables and their adherence to the treatment prescribed (Golin, Liu, Hays et al. 2004; Osterberg \& Blaschke, 2005 ).

Furthermore, several Authors (e.g. Munro, Lewin, Swart \& Volmink, 2007; Sidat, Fairley \& Grierson, 2007) have highlighted the importance of motivation in adherence, since the individual's motivation is central to most theories used to study health behaviour for the purposes of either prediction or behaviour change.

It must be noted, that the most commonly investigated theories of health behaviour, such as social-cognitive theory and self-efficacy, share the central assumption that people are capable of forethought, planning, and rational decision making. Moreover, these theories explicitly or implicitly recognize that people experience their decision making and self-regulation, as part of a dynamic social learning process (Brawley \& Culos-Reed, 2000; Johnson, Catz, Remien et al., 2003).

However, none of these theories provides a comprehensive account of health outcomes, even though reliable but moderate effects on improving adherence have been demonstrated (Côté \& Godin, 2005; Reynolds, 2004).

Conversely, several factors related to patients' psychological features, health beliefs or expectations and quality of doctor-patient relationships had already proved to be statistically related to adherence to HAART in various crosssectional studies (e.g. Ironson, O'Cleirigh, Fletcher, et al., 2005; O'Cleirigh, 
Ironson, Weiss \& Costa, 2007; Penedo, Gonzalez, Dahn, et al., 2003; Spire, Duran, Souville et al., 2002;).

Starting from these theoretical and research considerations, this pilot study tried to identify the different psychological profiles relating to adherent or non-adherent subjects. 


\section{Method}

Four-hundred seventy-eight HIV+ subjects $(\% \mathrm{~F}=28.5)$ were enrolled in this study. All the subjects were volunteers and gave their written informed consent. All the subjects met the following inclusion criteria: (a) HIV+ diagnosis for at least 6 months, (b) protease and trascriptase inhibitors antiretroviral therapy prescribed, (c) therapy taking for at least 6 months. These criteria were selected to try and avoid bias due to the initial phase of adaptation to the diagnosis and to HAART. Mean age was $38.9 \pm 6.1$ years

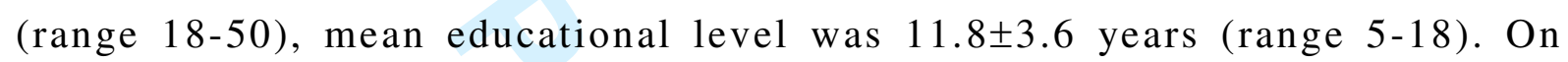
the basis of replies to the Questionnaire on Antiretroviral Therapy Taking (QUF, see below), the total sample was then divided into four subgroups: 202(42.3\%) adherent males, 140(29.3\%) non-adherent males, 66(13.8\%) adherent females and 70(14.6\%) non-adherent females. Adequate adherence was defined as $95 \%$ correct therapy taking during the last month, following Paterson's suggestions (Paterson, Swindells, Mohr, et al., 2000). No substantial differences were found in Age and Education as related to Adherence and to Gender.

Measures. All the subjects were administered a battery of tests, including a Socio-Demographic Schedule, a Questionnaire on Antiretroviral Therapy Taking (QUF), the Attachment Style Questionnaire (ASQ; Feeney, Noller, \& Hanrahan, 1994; Fossati, Feeney, Donati, et al, 2003) and the Multidimensional Health Locus of Control Form-C (MHLC-C; Ubbiali, Donati, Chiorri et al., 2007; Wallston, Stein, \& Smith, 1994)

The QUF is a 15-item self-administered questionnaire developed by a group of psychologists from the San Raffaele Hospital of Milan, in order to assess 
HIV + subjects' therapy taking, attendance at scheduled visits, and behaviours related to therapeutic regimen.

The ASQ is a 40-item, Likert type, self-administered questionnaire, designed to measure five dimensions of Adult Attachment: Confidence, Discomfort with Closeness, Need for Approval, Preoccupation with Relationships and Relationships as Secondary. Although Confidence is clearly a factor representing Secure Adult Attachment, each of the other four scales represents a particular aspect of insecure attachment (Feeney, Noller, \& Hanrahan, 1994).

The MHLC-C, is an 18-item self-administered questionnaire, useful for assessing Locus of Control beliefs about any health condition. MHLC-C is divided in 4 scales: Internality, Chance, Doctors and Other People. Differences in ASQ and MHLC-C mean scale scores among groups were tested through a Mixed Factorial Analysis of Variance (Mixed ANOVA) for each test, taking into account Scale Mean Scores as repeated measure factor, Gender and Adherence as between-subject factors. 


\section{Results}

The Mixed ANOVA performed on MHLC-C scores showed a significant effect of Scale $(F(2.71,1667.05)=382.389, p<.001)$ and Adherence $(F(1,474)=4.070$, $p=.044)$. Bonferroni-adjusted post-hoc tests revealed that Doctors score was higher than any other and that the Internality score was higher than Chance and Other People, which did not differ. However, given that the main goal of this study was to explore differences in score profiles between males and females, Bonferroni-adjusted mean multiple comparisons were performed on each level of gender. It emerged that adherent males scored significantly higher than non-adherent males both on Doctors and Other People $(p=.025$ and $p=.010$, respectively), while the same pattern did not hold for females (Figure 1).

The Mixed ANOVA performed on ASQ scores showed a significant effect of Scale $(F(3.23,1528.87)=372.690, p<.001)$, of Scale by Adherence interaction $(F(3.23,1528.87)=3.661, p=.010)$, and of Adherence $(F(1,474)=4.939$, $p=.027)$. Bonferroni-adjusted post-hoc tests revealed that mean scores of any subscale differed from those of any other, with Confidence receiving the highest mean ratings, consistently with the normative Italian sample (Fossati et al., 2003).

In general, adherent subjects had lower scores than non-adherent both in Need for Approval and Preoccupation with Relationships $(p=.004$ and $p=.012$, respectively), but when multiple comparisons were separately performed on a gender basis, it emerged that this pattern held only for females. Interestingly, among males, adherent subjects scored lower than non-adherent on Relationships as Secondary ( $p=.014)$ (Figure 2). 


\section{Discussion}

Primarily, these results revealed that both adherent and non-adherent subjects obtained ASQ Confidence and MHLC-C Internality scores comparable to those of the general population.

However, some (non-pathological) psychological features may interfere with medium and long-term adherence to HAART.

In particular, the psychological profile of non-adherent males seemed to be less focused on relational aspects (non-adherent > adherent on ASQ Relationship as Secondary), on the perceived relevance of physicians (adherent < non-adherent on MHLC-C Doctors) and of 'significant other people' (adherent < non-adherent on MHLC-C Other People). In a different way, the profile of non-adherent females seemed to be more 'relationshiporiented' (non-adherent $>$ adherent on ASQ Need for Approval and on ASQ Preoccupation with Relationships).

On the whole, the results of this study seem to suggest gender-specific relational issues. Non-adherent males appear to have developed a kind of withdrawal from the world of relationships, especially from those with emotional implications.

Several Authors have pointed out that adherence to the HAART regimen requires not only individual coping skills, but also the presence of a "network of relationships' capable of enhancing HIV+ patients' quality of life. A similar relational gap may play an important role in the non-adherence phenomenon.

Conversely, non-adherent females do not seem to avoid relationships, but rather, worry excessively about negative feedback or possible refusals by others. It seems reasonable that this need for approval and/or this fear of 
being left alone or neglected can cause their vigilance over their pathology to decrease and consequently their commitment to HAART.

\section{Conclusion}

This study has some limitations, such as the use of self-reported measures. However, many previous studies on HIV subject's adherence, showed that these methods are quite reliable for long-term follow-up in clinical settings. Furthermore, our sample cannot be considered fully representative of HAART treated patients, due to different male/female sample sizes, lack of personality assessment and subjects not stating their sexual orientation. A further self-selection bias may have occurred due to the well-known HIVrelated Unit in our hospital causing other groups of patients to be underrepresented.

Despite limitations, our results might encourage further reflection on the advisability of planning specific support for strengthening adherence to HAART by taking into consideration the possible difference in male and female perception of the pathology. 


\section{References}

Barclay, T. R., Hinkin, C. H., Castellon, S. A., Mason, K. I., Reinhard, M. J., Marion, S. D., Levine A. J., \& Durvasula, R. S. (2007). Age-associated predictors of medication adherence in HIV-positive adults: health beliefs, self-efficacy, and neurocognitive status. Health Psychology, 26(1), 40-49.

Brawley, L.R., \& Culos-Reed, N. (2000) Studying Adherence to Therapeutic Regimens Overview, Theories, Recommendations. Controlled Clinical Trials, 21(5), 156-163.

Conway, B. (2007). The role of adherence to antiretroviral therapy in the management of HIV infection. Journal of Acquired Immune Deficiency Syndromes, 45 Suppl. 1, S14-18.

Côté J.K., \& Godin, G. (2005). Efficacy of interventions in improving adherence to antiretroviral therapy. International Journal of STD AIDS, 16(5), 335-343.

Feeney, J.A., Noller, P., \& Hanrahan, M. (1994). Assessing Adult Attachment. In M.B. Sperling \& W.H. Berman (Eds.), Attachment in Adults: Clinical and Developmental Perspectives (pp. 128-152). New York: The Guilford Press.

Fogarty, L., Roter, D., Larson, S., Burke, J., Gillespie, J., \& Levy, R. (2002). Patient adherence to HIV medication regimens: a review of published and abstract reports. Patient Education and Counseling, 46, 93-108.

Fossati, A., Feeney, J.A., Donati, D., Donini, M., Novella,L., Bagnato, M., Acquarini, E., \& Maffei, C. (2003). On the dimensionality of the Attachment Style Questionnaire in Italian clinical and nonclinical subjects. Journal of Social and Personal Relationships, 20, 55-79.

Golin C. E., Liu H., Hays R. D., Miller L. G., Beck C. K., Ickovics J., Kaplan A. H., \& Wenger N. S. (2002). A prospective study of predictors of adherence to combination antiretroviral medication. Journal of General and Internal Medicine, 17(10), 756-765.

Ironson, G., O'Cleirigh, C., Fletcher, M. A., Laurenceau, J. P., Balbin, E., Klimax, N., Schneiderman N., \& Solomon, G. (2005). Psychosocial factors predict CD4 and viral load change in men and women with human 
immunodeficiency virus in the era of highly active antiretroviral treatment. Psychosomatic Medicine, 67(6), 1013-1021.

Johnson, M. O., Catz, S. L., Remien, R. H., Rotheram-Borus, M. J., Morin S. F., Charlebois E., Gore-Felton, C., Goldsten, R. B., Wolfe, H., Lightfoot, M., Chesney, M. A. \& NIMH Healthy Living Project Team. (2003). Theory-guided, empirically supported avenues for intervention on HIV medication nonadherence: findings from the Healthy Living Project. AIDS Patient Care STDS, 17(12), 645-656.

Miller, L. G., \& Hays, R. D. (2000). Adherence to combination antiretroviral therapy: synthesis of the literature and clinical implications. The AIDS Reader, 10(3), 177-185.

Munro, S., Lewin, S., Swart, T., \& Volmink, J. (2007). A review of health behaviour theories: how useful are these for developing interventions to promote long-term medication adherence for TB and HIV/AIDS? BMC Public Health, 7, 104.

O'Cleirigh, C., Ironson, G., Weiss, A., \& Costa, P. T. Jr. (2007).

Conscientiousness predicts disease progression (CD4 number and viral load) in people living with HIV. Health Psychology, 26(4), 473-480.

Osterberg, L., \& Blaschke, T. (2005). Adherence to medication. New England Journal of Medicine, 353(5), 487-497.

Paterson, D. L., Swindells, S., Mohr, J., Brester, M., Vergis, E. N., Squier, C., Wagener, M. M., \& Singh, N. (2000). Adherence to Protease Inhibitor Therapy and Outcomes in Patients with HIV infection. Annals of Internal Medicine, 133, 21-30.

Penedo, F. J., Gonzalez, J.S., Dahn, J. R., Antoni, M., Malow, R., Costa, P., \& Schneiderman, N. (2003). Personality, quality of life and HAART adherence among men and women living with HIV/AIDS. Journal of Psychosomatic Research, 54(3), 271-278.

Reynolds N. R. (2004). Adherence to antiretroviral therapies: state of the science. Current HIV Research, 2(3), 207-214.

Sidat, M., Fairley, C., \& Grierson, J. (2007). Experiences and perceptions of patients with $100 \%$ adherence to highly active antiretroviral therapy: a qualitative study. AIDS Patient Care STDS, 21(7), 509-520. 
Spire, B., Duran, S., Souville, M., Leport, C., Raffi F., Moatti, J.P., \& the APROCO cohort study group (2002). Adherence to highly active antiretroviral therapies (HAART) in HIV-infected patients: from a predictive to a dynamic approach. Social Science \& Medicine, 54, 14811496.

Ubbiali, A., Donati, D., Chiorri, C., Bregani, V., Cattaneo, E., Maffei, C., \& Visintini, R. (submitted). The usefulness of the Multidimensional Health Locus of Control Form-C (MHLC-C) for HIV+ subjects: an italian study. AIDS care.

Wallston K. A., Stein, M. J., \& Smith, C. A. (1994). Form-C of MHLC scales: A Condition-Specific Measure of Locus of Control. Journal of Personality Assessment, 63(3), 534-553. 
Figure 1 MHLC-C Scale by Adherence by Gender Interaction Plot (estimated marginal means)

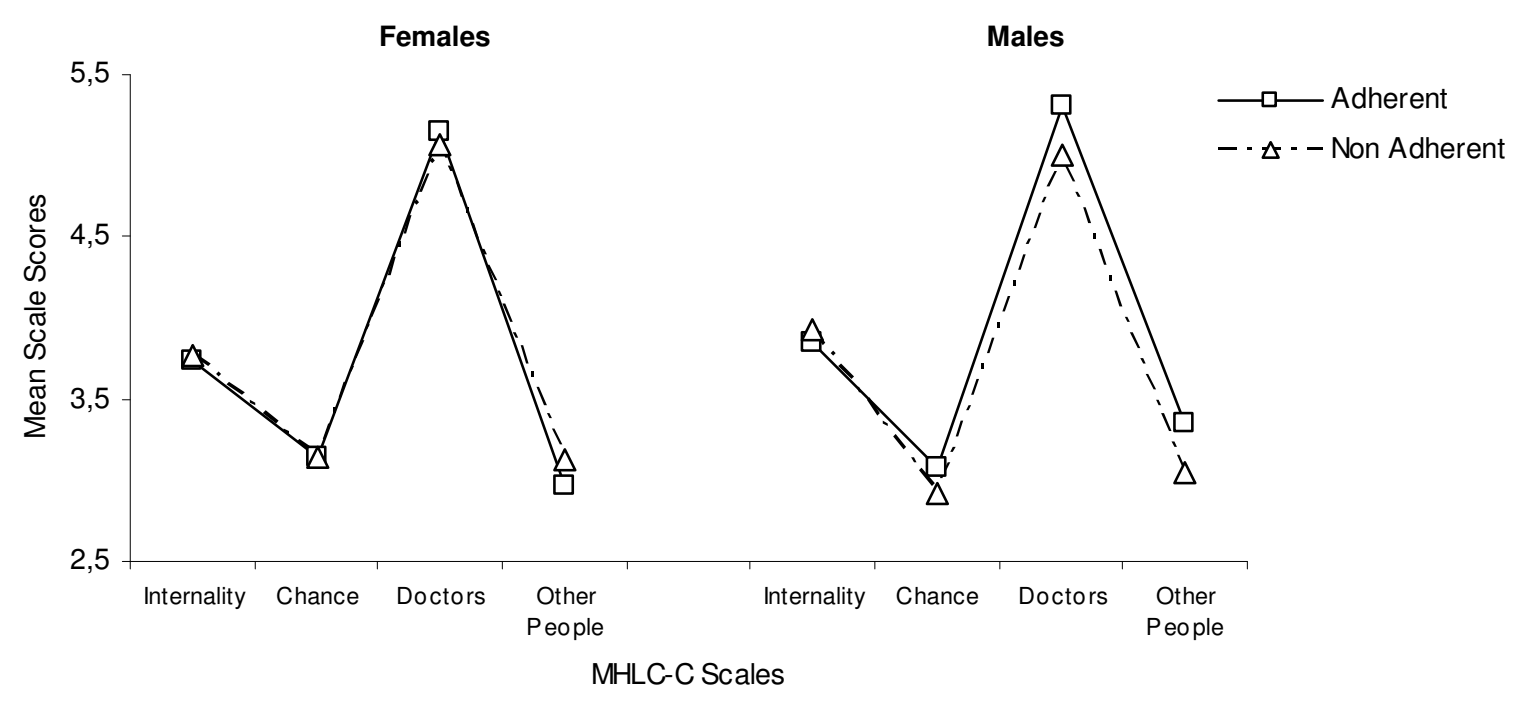


Figure 2 ASQ Scale by Adherence by Gender Interaction Plot (estimated marginal means)

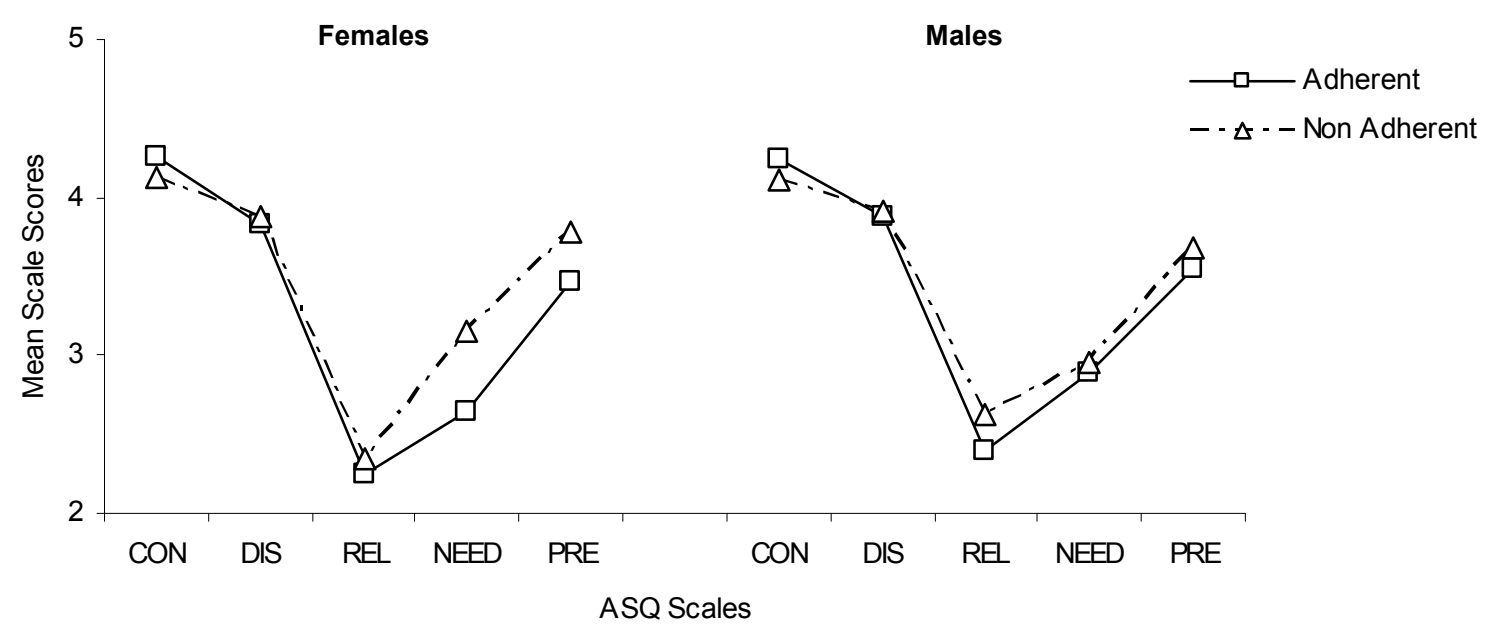

NOTE: $\mathrm{CON}=$ Confidence; $\mathrm{DIS}=$ Discomfort with Others; $\mathrm{REL}=$ Relationships as Secondary; $\mathrm{NEED}=$ Need for Approval; $\mathrm{PRE}=$ Preoccupation with Relationships 